\title{
School Leadership and Teachers' Pedagogical Orientations in Hong Kong: A Comparative Perspective
}

\author{
Allan H.K. Yuen, M.W. Lee, Nancy Law \\ Centre for Information Technology in Education \\ The University of Hong Kong \\ Pofulam Road, Hong Kong \\ Email: hkyuen@hku.hk
}

\begin{abstract}
As a secondary analysis of SITES 2006, this paper aims to explore the school leadership factors that potentially affect teachers' pedagogical orientations. The exploration is guided by four questions: (1) How do we describe school leadership factors? (2) What are the principals' perceptions about pedagogy and ICT use? (3) What are the teachers' perceptions about pedagogical orientations? and (4) How does the school leadership associate with teachers' pedagogical orientations? Eight school leadership constructs were identified, which cover four areas: learning goals, priority for resource allocation, types of assessment, and priority of competencies for school leadership to acquire. The findings also indicate a gap between principals' and teachers' perceptions on pedagogy and ICT use in Hong Kong.
\end{abstract}

Keywords: school leadership, ICT integration, pedagogical orientation, comparative perspective

\section{Introduction}

During the past decade there has been an exponential growth in the use of information and communication technology (ICT) in all aspects of everyday life, which has created changes in society and economy. In addition to the growth of ICT use, the emergence of the knowledge and skills students need in the $21^{\text {st }}$ century has brought about a much greater emphasis on education (UNESCO 2002). In response to these challenges, policies on education reform and ICT in education have been developed in many countries (Pelgrum and Anderson 1999; Anderson and Plomp 2008). In 1998, the Hong Kong Government announced the first ICT in education policy document - "Information Technology for Learning in a New Era: Five-year Strategy" (EMB 1998). This document signified the Government's commitment to driving Hong Kong to become a leader, not a follower, in the information world of tomorrow, as stated at the beginning of the document that students "need to develop habits of life-long learning so as to ride on the tides of rapid changes" (p.1). 
Furthermore, the aims of education for the $21^{\text {st }}$ century was advocated in the reform proposals for the education system in Hong Kong (EC 2000), with an emphasis on enabling students to "attain all-round development according to their own attributes in the domains of ethics, intellect, physique, social skills and aesthetics, so that they are capable of life-long learning, critical and exploratory thinking, innovating and adapting to change; filled with self-confidence and a team spirit; willing to put forward continuing effort for the prosperity, progress, freedom and democracy of their society, and contribute to the future and wellbeing of the nation and the world at large" (p. 4).

These policies reveal that educational innovations in ICT have been embedded within a broader framework of education reform that aimed to bring about a new culture in learning and teaching and to develop students' capacities for self-learning, problem-solving, information seeking and analysis, and critical thinking, as well as the ability to communicate, collaborate and learn, abilities that figured much less importantly in previous school curricula (Yuen et al. 2003). In the second ICT in education policy document, "Empowering Learning and Teaching with Information Technology" (EMB 2004), it encouraged students, teachers, schools and other stakeholders to use ICT effectively as a tool for enhancing the effectiveness of learning and teaching, with a view to preparing our younger generation for the information age. Enhancing school leadership for the information age was also a major goal of the second policy document.

Between 1998 and 2006, there have been great improvements in accessing computers and the Internet, and the available ICT infrastructure in schools across various education systems, especially in Hong Kong. The mean student-computer ratio in Hong Kong was decreased from 23:1 in 1998 to 6:1 in 2006, indicating that the accesses of computers by students have been substantially improved. Pedagogical support and technical support available for ICT-use in schools were relatively high in Hong Kong. As reported by school principals in the SITES-M1 and SITES 2006, there is general increases in the perceived presence of lifelong-learning pedagogy in schools between 1998 and 2006. Hong Kong is one such system having comparatively high presence of lifelong-learning pedagogy in Asia. However, a decrease in presence of lifelong-learning pedagogy was reported in three European systems that registered the highest presence in 1998, including Slovenia, Denmark, and Norway (Pelgrum 2008). These findings raise a number of questions regarding school leadership and pedagogical orientations that deserve further investigation.

This paper aims to explore the relations between the changes that occurred in teachers' pedagogical orientations and school leadership. Further to the research findings of the SITES projects, a secondary analysis of the SITES 2006 data was conducted. The secondary analysis takes a comparative perspective and attempts to understand the school leadership factors that potentially affect teachers' pedagogical orientations, and how the teacher-level and school-level factors are associated. The exploration is guided by four questions: (1) How do we describe school leadership factors? (2) What are the principals' perceptions about pedagogy and ICT use? (3) What are the teachers' perceptions about pedagogical orientations? and (4) How does the school leadership associate with teachers' pedagogical orientations? The second and third questions are focused on Hong Kong in contrast with Slovenia and Finland.

\section{Theoretical Framework}

How does ICT integration occur within schools? A list of factors that can potentially affect the use of ICT in schools has been suggested, such as organizational factors, support factors and environmental factors (Sumner and Hostetler 1999). In particular, teachers' and principals' perceptions are highlighted in the literature of school ICT integration (Yuen and Ma 2002; Coffland and Strickland 2004; McGrail 2005; Levin and Wadmany 2008). Recently, it is argued that the right combination of vision, compromise, and commitment of administrators and teachers is crucial in making fundamental and sustainable change possible (Leskes et al. 2003). 
If ICT is to be integrated into the school curriculum, the meaning of educational leadership and the role of the school principals within a technological change must be redefined (Bennett 1996). Kearsley and Lynch (1992) believe that a cultural view of leadership is most useful in understanding ICT integration in education, in which leaders are expected to shape the culture of individual school by creating new visions that organizational members can believe and act upon. Then, what considerations must be made to effectively plan and implement ICT integration in schools? Bennett (1996) argues that both cultural as well as physical environment within a school are important factors to be considered in ICT integration. Flanagan and Jacobsen (2003) suggest a contextual framework with which school principals can undertake new responsibilities and roles as technology leader, including leader of learning, leader of student entitlement, leader of capacity building, leader of community, and leader of resource management.

Yuen et al. (2003) reported the findings of an analysis on models of change amongst 18 schools in their efforts to integrate ICT in school curricula. It shows that the strategy adopted by a school in instituting such change and the resulting variation of pedagogical practices using ICT is strongly dependent on the school leaders' vision and understanding of the role and impact of ICT in the curriculum, their goals and objectives for ICT integration, as well as the history, culture and background of the school and its general vision and mission. Yet teachers tend to look at ICT and its role in pedagogical practices from the perspective of a practitioner and realist with an understanding of their own limitations and constraints in schools (McGrail 2005). It seems clear that teachers and principals often hold distinct views on the pedagogical use of ICT (Coffland and Strickland 2004); however, little empirical evidence has been offered to account for such issues of differences. The present study attempts to provide an empirical exploration of the relations between school leadership and teachers' pedagogical orientations in ICT use.

Based on the analysis of the SITES-M2 data, Owston (2003) proposes a tentative model for sustainability of classroom innovation, which emerged in two sets of conditions: (1) five essential conditions including teacher support, teacher professional development, student support, perceived value of innovation, and administrative support, and (2) five contribution conditions including innovative champions, supportive plans and policies, funding, support from outside school, and support within school. Essential conditions are conditions were found necessary but not sufficient for innovations to be sustained, whereas contribution conditions are conditions were found facilitated the sustainability of innovations. Zhao and Frank (2003) propose an ecological metaphor to integrate and organize a set of factors that affect implementation of technology uses in schools, in which they suggest that "innovations cannot be implemented without regard to the internal social structures of schools or other pressures that schools face" (p. 833). Both "model for sustainability" and "ecological system" indicate a systems approach is needed to the understanding of internal as well as contextual factors in the implementation of educational innovation in schools. Likewise, the present study takes a systemic perspective, in which two major components of a school system, i.e. principals and teachers, are investigated to explore the interactions between school leadership and pedagogical orientations.

\section{Research Methodology}

\subsection{Participants}

Across the 22 participated education systems in SITES 2006, data collected from 12 systems met IEA's minimum participation rate requirement, i.e. at least $70 \%$ of the sampled schools in each system need to be participated. They include Catalonia, Chile, Chinese Taipei, Finland, Hong Kong, Israel, Italy, Japan, Ontario Province, Singapore, Slovak Republic, and Slovenia. The data of these 12 systems were used in the analysis to address the first and fourth research question. Of these 12 systems, we are particularly interested in studying the education systems in Hong Kong, Finland, and Slovenia. It is because the SITES 2006 study has identified that there are significant changes in the presence of emerging pedagogy between SITES-M1 and SITES 2006 in some systems, particularly in Hong Kong and Slovenia (Pelgrum 2008). The 
presence of emerging pedagogy in Hong Kong was substantially increased since the SITES-M1 study, whilst the presence of that was decreased in Slovenia. Such variations suggested that principals' perception on emerging pedagogy in Hong Kong and Slovenia are changing in two different directions. Finland is a system having similar indication of emerging pedagogy in SITES-M1 and SITES 2006, indicating that changes of principals' perception on emerging pedagogy is not noticeable. As such, the data analysis of Finland, Hong Kong, and Slovenia would offer a meaningful comparative perspective for the exploration of the second and third reserch question. The sample size of the study in Hong Kong, Finland, and Slovenia are summarized as follows (Table 1).

Table 1 Sample size of the selected education systems

\begin{tabular}{lll}
\hline Education System(s) & Number of schools participated & Number of teachers participated \\
\hline 12 selected education systems & 4523 & 15627 \\
Hong Kong & 304 & 1163 \\
Finland & 355 & 1178 \\
Slovenia & 388 & 1576 \\
\hline
\end{tabular}

Data collected in each system were hierarchically structured. Specifically, schools were randomly sampled from each of the participating systems, and principals and technology coordinators in each system were invited to complete the principal and technical questionnaire respectively. Two to four mathematics and/or science teachers teaching at the target grade (Grade 8) were also selected respectively from each of the sampled schools. As such, the collected data were hierarchical structured in a way that teacher data nested within schools and school data nested within education systems.

\subsection{Teacher-level Constructs}

A number of teacher-level constructs were derived by Law and Chow (2008) based on the findings from the teacher questionnaire. Amongst these constructs, 12 of them related to two aspects were selected in the present analysis (see Table 2), namely teacher-practice (TP) pedagogical orientation and student-practice (SP) pedagogical orientation. Constructs related to the TP pedagogical orientation were derived from teacher responses to the questions "How often do you conduct the following activities?" and "Do you use ICT for these activities?", whereas that related to the SP pedagogical orientation were derived from teacher responses to the questions "How often do your students engage in the following activities?" and "Do your students use ICT for these activities?" (IEA 2008).

Table 2 Constructs related to pedagogical-practice orientations

\begin{tabular}{ll}
\hline Constructs & Descriptions (Number of items and Cronbach's alpha) \\
\hline TP_TRAD & $\begin{array}{l}\text { Traditionally important teacher-practice orientation such as present } \\
\text { information/demonstrations and/or give class instructions ( } 3 \text { items; } \alpha=0.58)\end{array}$ \\
TP_LLL & $\begin{array}{l}\text { Lifelong learning teacher-practice orientation such as help students in exploratory } \\
\text { and inquiry activities }(6 \text { items; } \alpha=0.81)\end{array}$ \\
TP_CONN & $\begin{array}{l}\text { Connectedness teacher-practice orientation such as organize and/or mediate } \\
\text { communication between students and experts/external mentors (3 items; } \alpha=0.71)\end{array}$ \\
SP_TRAD & $\begin{array}{l}\text { Traditionally important student-practice orientation such as complete } \\
\text { worksheets/exercises }(1 \text { item } *)\end{array}$ \\
SP_LLL & $\begin{array}{l}\text { Lifelong learning Student-practice orientation such as students learning and/or } \\
\text { working during lessons at their own pace }(6 \text { items; } \alpha=0.75)\end{array}$ \\
SP_CONN & Connectedness student-practice connectedness orientation such as contribute to the \\
ICT_TP_TRAD & $\left.\begin{array}{l}\text { community through their own learning activities }(3 \text { items; } \alpha=0.73) \\
\text { ICT-using traditionally important teacher-practice orientation }(3 \text { items } * *)\end{array}\right)$ \\
ICT_TP_LLL & ICT-using lifelong learning teacher-practice orientation $(6$ items $* *)$ \\
ICT_TP_CONN & ICT-using connectedness teacher-practice orientation $(3$ items $* *)$
\end{tabular}


ICT_SP_TRAD ICT-using traditionally student-practice important orientation $(1$ item**)

ICT_SP_LLL ICT-using lifelong learning student-practice orientation $(6$ items**)

$\mathrm{ICT}^{-} \mathrm{SP}^{-} \mathrm{CONN}$ ICT-using connectedness student-practice orientation $(3$ items**)

* Single item construct; ** Yes/No response items

\subsection{Data Analysis Strategy}

Different statistical analyses were employed to address the identified research questions. Initially, an exploratory factor analysis (EFA) method was employed to derive the school leadership factors from the principal questionnaire. Subsequently, analysis of variance (ANOVA) was used to compare principals' perceptions about pedagogy and ICT use and teachers' perceptions about pedagogical orientation in Hong Kong, Finland, and Slovenia. Finally, a hierarchical linear modeling approach was employed to study the interactions between school leaderships and teachers' pedagogical orientations. The use of hierarchical linear modeling method was considered to be appropriate because it analyses multi-level data simultaneously to avoid possible aggregation and disaggregation biases, and it is capable to model crosslevel interactions effect between group-level predictors and individual-level independent variables on outcome variables (Tse et al. 2008; Griffin 2001; Hofmann et al. 2000). To explore the effects of school leaderships on the 12 teachers' pedagogical orientaions, 12 three-level hierarchical linear models were developed by using a software package, HLM (Raudenbush et al. 2004). The structures of the 12 models were similar despite the variations of the outcome variables (dependent variables). More specifically, there is no level-1 (teacher-level) predictor. The intercept score from Level-1 were used as dependent variables at level-2 (school-level), and eight school-level predictors were included in this level. A dummy variable was used at Level-3 (system-level), with the scores of intercept and slope from Level-2 as dependent variables. A significant variance component at level-3 indicates the differences between systems, whereas that at level-2 indicates the differences between schools.

\section{Results}

In this section, first of all, the development of school leadership constructs is described. Then, principals' perceptions on pedagogy and ICT use and teachers' pedagogical orientations are presented. Finally, the interactions of school-level and teacher-level are discussed.

\subsection{Development of School Leadership Constructs}

How do we describe school leadership factors? In this study, EFA was used to examine the factor structure of each of the questions within the principal questionnaire. Findings from the analysis showed that eight school leadership constructs can be identified from four questions within the principal questionnaire.

To answer the question "to what extent do you agree or disagree that the school leadership encourages Mathematics and Science teachers at Grade 8 to achieve the following goals?", principals were asked to response ten items related to various learning goals. All items were measured in a four-point Likert scale, with 1 as "strongly disagree", 2 as "disagree", 3 as "agree", and 4 as "strongly agree". Table 3 summarizes the key findings from the initial run of the EFA and reliability analysis (Cronbach's alpha).

Table 3 Constructs related to learning goals encouraged by school leadership 


\begin{tabular}{lllll}
\hline $\begin{array}{l}\text { Constructs } \\
\text { (No. of items) }\end{array}$ & Descriptions & $\alpha$ & $\begin{array}{l}\text { Eigen } \\
\text { value }\end{array}$ & $\begin{array}{l}\text { \% of } \\
\text { Variance }\end{array}$ \\
\hline $\begin{array}{l}\text { SLG_TRA } \\
(2 \text { items }\end{array}$ & $\begin{array}{l}\text { School leadership encourages traditional learning } \\
\text { goals, such as to improve students' performance } \\
\text { on examinations }\end{array}$ & 0.62 & 1.19 & 11.59 \\
& $\begin{array}{l}\text { School leadership encourages } 21^{\text {st }} \text { century } \\
\text { learning goals like to foster collaborative and } \\
\text { organizational skills when working in teams }\end{array}$ & 0.85 & 4.16 & 41.59 \\
\hline $\begin{array}{l}\text { SLG_21C } \\
(8 \text { items }\end{array}$ & & & \\
\hline
\end{tabular}

Note: ${ }^{*}$ Factor loading of each item is ranged from 0.49 to 0.75

Principals were asked: "What priority level do you give to resource allocation in your school in order to enhance the use of ICT in teaching and learning for the Grade 8 students in your school?" Respondents were requested to indicate the degree of priority giving to eleven items related to various aspects of resource. All items were measured in a four-point Likert scale, with 1 as "not a priority", 2 as "low priority", 3 as "medium priority", and 4 as "high priority". Table 4 illustrates the two factors extracted from the initial run.

Table 4 Constructs related to priority for resource allocation to enhance ICT use

\begin{tabular}{|c|c|c|c|c|}
\hline $\begin{array}{l}\text { Constructs } \\
\text { (No. of items) }\end{array}$ & Descriptions & $\alpha$ & $\begin{array}{l}\text { Eigen } \\
\text { value }\end{array}$ & $\begin{array}{l}\% \text { of } \\
\text { Variance }\end{array}$ \\
\hline $\begin{array}{l}\text { PRA_INF } \\
\left(5 \text { items }^{*}\right)\end{array}$ & $\begin{array}{l}\text { Priority for infrastructure resource allocation to } \\
\text { enhance ICT use, e.g. to increase the number of } \\
\text { computers connected to the Internet }\end{array}$ & 0.84 & 1.63 & 14.84 \\
\hline $\begin{array}{l}\text { PRA_PEOP } \\
\left(6 \text { items }^{*}\right)\end{array}$ & $\begin{array}{l}\text { Priority for people resource allocation to enhance ICT } \\
\text { use, e.g. to improve the ability of teachers to make } \\
\text { good pedagogical use of ICT }\end{array}$ & 0.80 & 5.03 & 45.76 \\
\hline
\end{tabular}

Note: ${ }^{*}$ Factor loading of each item is ranged from 0.46 to 0.89

Principals were asked: "To what extent do you agree or disagree that the school leadership encourages teachers to use each of the following types of assessment at Grade 8?" In this question, principals responded to eight items related to different types of assessment. All items were measured in a four-point Likert scale, with 1 as "strongly disagree", 2 as "disagree", 3 as "agree", and 4 as "strongly agree". Table 5 illustrates the two factors extracted from an initial run.

Table 5 Constructs related to types of assessment encouraged by school leadership

\begin{tabular}{|c|c|c|c|c|}
\hline $\begin{array}{l}\text { Constructs } \\
\text { (No. of items) }\end{array}$ & Descriptions & $\alpha$ & $\begin{array}{l}\text { Eigen } \\
\text { value }\end{array}$ & $\begin{array}{l}\% \text { of } \\
\text { Variance }\end{array}$ \\
\hline $\begin{array}{l}\text { ASS_TRAD } \\
\left(3 \text { items }^{*}\right)\end{array}$ & $\begin{array}{l}\text { School leadership encourages teachers to use } \\
\text { traditional assessment, e.g. written } \\
\text { tests/examinations }\end{array}$ & 0.88 & 4.27 & 53.42 \\
\hline $\begin{array}{l}\text { ASS_EMER } \\
\left.\text { (5 items }{ }^{*}\right)\end{array}$ & $\begin{array}{l}\text { School leadership encourages teachers to use more } \\
\text { emerging assessment, e.g. group assessment scores } \\
\text { for collaborative tasks or students' peer } \\
\text { evaluations }\end{array}$ & 0.83 & 1.28 & 16.06 \\
\hline
\end{tabular}

Note: ${ }^{*}$ Factor loading of each item is ranged from 0.56 to 0.91

In responding to the question "how much of a priority is it for your school leadership to acquire competencies in the following areas", principals were asked to give response to ten items related to various competencies. All items were measured in a four-point Likert scale, with 1 as "not considered", 2 as "low priority", 3 as "medium priority", and 4 as "high priority". Table 6 illustrates the constructs extracted from the initial run. 
Table 6 Constructs related to priority of competencies for school leadership to acquire

\begin{tabular}{|c|c|c|c|c|}
\hline $\begin{array}{l}\text { Constructs } \\
\text { (No. of items) }\end{array}$ & Descriptions & $\alpha$ & $\begin{array}{l}\text { Eigen } \\
\text { value }\end{array}$ & $\begin{array}{l}\% \text { of } \\
\text { Variance }\end{array}$ \\
\hline $\begin{array}{l}\text { SLC_VIS } \\
\left(4 \text { items }^{*}\right)\end{array}$ & $\begin{array}{l}\text { Priority for school leadership to acquire visionary } \\
\text { competencies, such as developing vision, managing } \\
\text { innovation, encouraging collaboration }\end{array}$ & 0.72 & 1.24 & 12.39 \\
\hline $\begin{array}{l}\text { SLC_STRA } \\
\left(6 \text { items }^{*}\right)\end{array}$ & $\begin{array}{l}\text { Priority for school leadership to acquire strategic } \\
\text { competencies, such as identifying best practices, } \\
\text { developing strategic plans }\end{array}$ & 0.91 & 5.18 & 51.74 \\
\hline
\end{tabular}

Note: ${ }^{*}$ Factor loading of each item is ranged from 0.57 to 0.88

In summary, eight school leadership constructs are identified from the principal questionnaire. These constructs represent principals' perceptions on pedagogy and ICT use in schools, and they are used as indicators to describe school leadership factors.

\subsection{Principals' Perceptions on Pedagogy and ICT Use}

What are the principals' perceptions about pedagogy and ICT use? ANOVA of the 8 school leadership constructs were conducted across the three selected education systems, and findings are presented in Table 7. Fisher's protected least significant difference (LSD) post hoc test was employed to compare the findings of the three education systems, as such a test is the most powerful post hoc test for three groups (Cardinal and Aitken 2006). Table 7 shows that the mean scores of SLG_21C in Hong Kong and Slovenia are significantly higher than that in Finland. However, the mean differences between Hong Kong and Slovenia are not significant. Such a finding indicates that changes of the presence of 'a lot' emerging pedagogy in SITES 2006 (Pelgrum 2008) is unlikely to have a direct relationship to the school leadership who encourages $21^{\text {st }}$ century learning goals (SLG_21C). The post hoc test results in the priority of resource allocated to enhance ICT use shows that consideration of the priority to the infrastructure in Hong Kong are the lowest across the three selected education systems, whereas Slovenia has the highest priority to both the infrastructure and people resources. The most likely explanation is that there have been great improvements in ICT infrastructure in Hong Kong between 1998 and 2006. For the priority of competencies for school leadership to acquire, post hoc test results show that Hong Kong is a system having the lowest priority in acquiring competencies in the area of visionary and strategic. For assessment, the mean scores in encouraging teachers to use emerging as well as traditional assessment in Hong Kong is the highest across the three systems, indicating that principals in Hong Kong are mindful of assessment, no matter what the method is.

\subsection{Teachers' Pedagogical Orientations}

What are the teachers' perceptions about pedagogical use of ICT? ANOVA of the 12 teacher-level constructs were conducted across the three selected education systems, and a comparison of findings is presented in Table 8. The mean scores of each of the teacher-level constructs in Hong Kong, Finland, and Slovenia were compared (Table 8). The LSD post hoc test was also conducted for comparing the findings across the aforementioned education systems. As shown in the table, for all the eight $21^{\text {st }}$ century pedagogical orientations except ICT_TP_CONN and ICT_SP_LLL, the mean scores obtained by Slovenia are higher than that by Hong Kong, and Hong Kong scores are higher than Finland (i.e. Svn $>$ HK $>$ Fin). However, it ought to be noted that the post hoc test finding also shows that Hong Kong obtained the highest mean score in ICT_SP_LLL, but the lowest in ICT_TP_CONN. Regarding the four traditional pedagogical orientations, the mean scores obtained by Hong Kong is lower than Slovenia in TP_TRAD, but higher than Slovenia in SP_TRAD. Hong Kong obtained the highest mean score in ICT_TP_TRAD. Slovenia obtained the highest mean score in ICT_SP_TRAD, whereas Hong Kong is higher than Finland. Generally speaking, Slovenia and Finland obtained the highest and lowest mean scores respectively in most of the teacher-level constructs, whereas the mean scores of Hong Kong is in the middle. Clearly, it indicates a gap between 
principals' and teachers' perceptions on pedagogy and ICT use in Hong Kong schools as comparatively high presence of lifelong-learning pedagogy was perceived by principals in SITES 2006.

\subsection{School Leadership and Teacher Pedagogical Orientations}

To address the fourth research question, 12 three-level hierarchical linear models were developed. Such models were developed on the basis of the data collected from the selected 12 systems because the development of a hierarchical linear model requires a large amount of data, where the data collected from Hong Kong, Finland, and Slovenia are too limited. Thus, the results only indicate general associations of school leadership and pedagogical orientations amongst 12 systems than individual education systems.

Table 9 shows the outputs of the HLM models. Findings from Models 8, 9, 10 and 12 can be left out as such models are not statistically significant. The first model, Model 1, can be interpreted as: the teacher practice traditionally important orientation can be predicted by two school leadership factors, i.e. ASS_TRAD $(\beta=0.09, p<0.001)$ and SLC_STRA $(\beta=0.04, p<0.001)$. In other words, if school leaderships prefer to employ traditional assessment methods and have a priority to acquire strategic competencies, teachers in the school are more likely to adopt a traditionally important pedagogical orientation in their teaching activities. Likewise, the remaining seven significant models can be interpreted and described in a similar way.

There are three interesting findings in comparing the output of the 12 models. Firstly, it was found that SLC_STRA plays an important role in predicting teacher-level pedagogical orientations. Secondly, in all 12 systems, the created models show that there are significantly differences between schools in all pedagogical orientations. However, with an exception of the teacher practice lifelong learning orientation, variations of the pedagogical orientations across the 12 systems are not statistically significant. Finally, apart from SLC_STRA, also SLG_21C and SLC_VIS play a role in predicting teacher-level pedagogical orientations, indicating the importance of principals' perceptions on $21^{\text {st }}$ century learning goals and visionary competences for school leadership. 
Table 7 Comparison of the ANOVA findings across Finland, Hong Kong, and Slovenia on school leadership constructs

\begin{tabular}{|c|c|c|c|c|c|c|c|c|}
\hline \multirow[b]{2}{*}{ School Leadership constructs } & \multicolumn{2}{|c|}{ Finland } & \multicolumn{2}{|c|}{ Hong Kong } & \multicolumn{2}{|c|}{ Slovenia } & \multirow[b]{2}{*}{$F$} & \multirow[b]{2}{*}{ Post Hoc } \\
\hline & $\begin{array}{l}\text { Mean } \\
\text { (s.d.) }\end{array}$ & $\mathrm{N}$ & $\begin{array}{l}\text { Mean } \\
\text { (s.d.) }\end{array}$ & $\mathrm{N}$ & $\begin{array}{l}\text { Mean } \\
\text { (s.d.) }\end{array}$ & $\mathrm{N}$ & & \\
\hline $\begin{array}{l}\text { School leadership encourages } 21^{\text {st }} \text { century } \\
\text { learning goals }\end{array}$ & $\begin{array}{l}3.02 \\
(0.35)\end{array}$ & 585 & $\begin{array}{l}3.25 \\
(0.38)\end{array}$ & 328 & $\begin{array}{l}3.23 \\
(0.36)\end{array}$ & 383 & $57.76^{* * *}$ & HK, Svn $>$ Fin \\
\hline $\begin{array}{l}\text { School leadership encourages traditional learning } \\
\text { goals }\end{array}$ & $\begin{array}{l}3.30 \\
(0.43)\end{array}$ & 603 & $\begin{array}{l}3.28 \\
(0.46)\end{array}$ & 335 & $\begin{array}{l}3.30 \\
(0.44)\end{array}$ & 387 & 0.12 & $n-s$ \\
\hline $\begin{array}{l}\text { Priority for infrastructure resource allocation to } \\
\text { enhance ICT use }\end{array}$ & $\begin{array}{l}3.14 \\
(0.45)\end{array}$ & 588 & $\begin{array}{l}2.91 \\
(0.49)\end{array}$ & 334 & $\begin{array}{l}3.34 \\
(0.44)\end{array}$ & 379 & $78.73^{* * *}$ & Svn $>$ Fin $>$ HK \\
\hline $\begin{array}{l}\text { Priority for people resource allocation to enhance } \\
\text { ICT use }\end{array}$ & $\begin{array}{l}2.88 \\
(0.52)\end{array}$ & 585 & $\begin{array}{l}3.12 \\
(0.58)\end{array}$ & 331 & $\begin{array}{l}3.11 \\
(0.44)\end{array}$ & 371 & $33.47^{* * *}$ & HK, Svn $>$ Fin \\
\hline $\begin{array}{l}\text { Priority for school leadership to acquire visionary } \\
\text { competencies }\end{array}$ & $\begin{array}{l}3.43 \\
(0.37)\end{array}$ & 574 & $\begin{array}{l}3.32 \\
(0.39)\end{array}$ & 319 & $\begin{array}{l}3.55 \\
(0.35)\end{array}$ & 374 & $33.47^{* * *}$ & Svn $>$ Fin $>$ HK \\
\hline $\begin{array}{l}\text { Priority for school leadership to acquire strategic } \\
\text { competencies }\end{array}$ & $\begin{array}{l}2.85 \\
(0.45)\end{array}$ & 552 & $\begin{array}{l}2.78 \\
(0.44)\end{array}$ & 318 & $\begin{array}{l}2.78 \\
(0.49)\end{array}$ & 367 & $3.42^{*}$ & Fin $>$ Svn, HK \\
\hline $\begin{array}{l}\text { School leadership encourages teachers to use } \\
\text { traditional assessment }\end{array}$ & $\begin{array}{l}3.35 \\
(0.53)\end{array}$ & 573 & $\begin{array}{l}3.36 \\
(0.45)\end{array}$ & 326 & $\begin{array}{l}3.24 \\
(0.45)\end{array}$ & 379 & $7.29^{* *}$ & HK, Fin $>$ Svn \\
\hline $\begin{array}{l}\text { School leadership encourages teachers to use } \\
\text { emerging assessment }\end{array}$ & $\begin{array}{l}2.80 \\
(0.48) \\
\end{array}$ & 565 & $\begin{array}{l}3.22 \\
(0.42) \\
\end{array}$ & 319 & $\begin{array}{l}3.07 \\
(0.45) \\
\end{array}$ & 375 & $97.86^{* * *}$ & HK $>$ Svn $>$ Fin \\
\hline 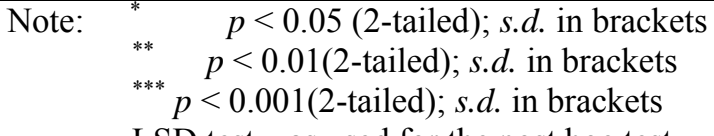 & & & & & & & & \\
\hline
\end{tabular}

LSD test was used for the post hoc test 
Table 8 Comparison of the ANOVA findings across Finland, Hong Kong, and Slovenia on teacher-level constructs

\begin{tabular}{|c|c|c|c|c|c|c|c|c|}
\hline Pedagogical-practice orientations & $\begin{array}{l}\text { Finland } \\
\text { Mean } \\
\text { (s.d.) }\end{array}$ & $\mathrm{N}$ & $\begin{array}{l}\text { Hong K } \\
\text { Mean } \\
\text { (s.d.) }\end{array}$ & $\mathrm{N}$ & $\begin{array}{l}\text { Slovenia } \\
\text { Mean } \\
\text { (s.d.) }\end{array}$ & $\mathrm{N}$ & $F$ & Post Hoc \\
\hline Traditionally important teacher practice orientation & $\begin{array}{l}3.05 \\
(0.57)\end{array}$ & 1124 & $\begin{array}{l}3.09 \\
(0.59)\end{array}$ & 1081 & $\begin{array}{l}3.15 \\
(0.51)\end{array}$ & 1488 & $11.13^{* * *}$ & Svn $>$ HK, Fin \\
\hline Lifelong-learning teacher practice orientation & $\begin{array}{l}2.29 \\
(0.43)\end{array}$ & 1099 & $\begin{array}{l}2.36 \\
(0.50)\end{array}$ & 1059 & $\begin{array}{l}2.80 \\
(0.54)\end{array}$ & 1453 & $407.49^{* * *}$ & Svn $>$ HK $>$ Fin \\
\hline Connectedness teacher practice orientation & $\begin{array}{l}1.60 \\
(0.43)\end{array}$ & 1097 & $\begin{array}{l}1.82 \\
(0.58)\end{array}$ & 1071 & $\begin{array}{l}2.38 \\
(0.61)\end{array}$ & 1471 & $682.97^{* * *}$ & Svn $>$ HK $>$ Fin \\
\hline Traditionally important student practice orientation & $\begin{array}{l}3.30 \\
(0.71)\end{array}$ & 1109 & $\begin{array}{l}3.29 \\
(0.73)\end{array}$ & 1065 & $\begin{array}{l}3.02 \\
(0.56)\end{array}$ & 1495 & $79.06^{* * *}$ & Fin, $\mathrm{HK}>\mathrm{Svn}$ \\
\hline Lifelong-learning student practice orientation & $\begin{array}{l}1.78 \\
(0.35)\end{array}$ & 1064 & $\begin{array}{l}2.01 \\
(0.51)\end{array}$ & 1026 & $\begin{array}{l}2.08 \\
(0.39)\end{array}$ & 1430 & $158.57^{* * *}$ & Svn $>$ HK $>$ Fin \\
\hline Connectedness student practice orientation & $\begin{array}{l}1.20 \\
(0.34)\end{array}$ & 1079 & $\begin{array}{l}1.34 \\
(0.53)\end{array}$ & 1056 & $\begin{array}{l}1.51 \\
(0.45)\end{array}$ & 1438 & $142.93^{* * *}$ & Svn $>$ HK $>$ Fin \\
\hline $\begin{array}{l}\text { ICT-using traditionally important teacher practice } \\
\text { orientation }\end{array}$ & $\begin{array}{l}16.48 \\
(24.03)\end{array}$ & 1062 & $\begin{array}{l}45.76 \\
(28.93)\end{array}$ & 1006 & $\begin{array}{l}29.83 \\
(30.64)\end{array}$ & 1391 & $277.79^{* * *}$ & $\mathrm{HK}>\mathrm{Svn}>$ Fin \\
\hline ICT-using lifelong-learning teacher practice orientation & $\begin{array}{l}15.29 \\
(18.97)\end{array}$ & 965 & $\begin{array}{l}24.24 \\
(28.42)\end{array}$ & 922 & $\begin{array}{l}28.01 \\
(27.61)\end{array}$ & 1324 & $70.30^{* * *}$ & $\mathrm{Svn}>\mathrm{HK}>$ Fin \\
\hline ICT-using connectedness teacher practice orientation & $\begin{array}{l}19.13 \\
(28.38)\end{array}$ & 967 & $\begin{array}{l}12.70 \\
(27.19) \\
\end{array}$ & 919 & $\begin{array}{l}20.93 \\
(28.88) \\
\end{array}$ & 1352 & $24.24^{* * *}$ & Svn,Fin $>\mathrm{HK}$ \\
\hline $\begin{array}{l}\text { ICT-using traditionally important student practice } \\
\text { orientation }\end{array}$ & $\begin{array}{l}23.16 \\
(42.21)\end{array}$ & 1075 & $\begin{array}{l}28.61 \\
(45.22)\end{array}$ & 1003 & $\begin{array}{l}39.85 \\
(48.98)\end{array}$ & 1423 & $43.22^{* * *}$ & Svn $>$ HK $>$ Fin \\
\hline ICT-using lifelong-learning student practice orientation & $\begin{array}{l}12.50 \\
(18.97)\end{array}$ & 924 & $\begin{array}{l}22.31 \\
(28.17)\end{array}$ & 880 & $\begin{array}{l}20.24 \\
(24.53)\end{array}$ & 1306 & $42.80^{* * *}$ & $\mathrm{HK}>\mathrm{Svn}>$ Fin \\
\hline ICT-using connectedness student practice orientation & $\begin{array}{l}8.78 \\
(21.58)\end{array}$ & 934 & $\begin{array}{l}11.56 \\
(25.64)\end{array}$ & 900 & $\begin{array}{l}21.89 \\
(31.74)\end{array}$ & 1334 & $73.56^{* * *}$ & Svn $>$ HK $>$ Fin \\
\hline
\end{tabular}

Note: $\quad{ }^{* * *} p<0.001(2$-tailed); s.d. in brackets

LSD test was used for the post hoc test 
Table 9 Summary of key results for the HLM models for 12 educational systems

\begin{tabular}{|c|c|c|c|c|c|c|c|c|c|c|}
\hline \multirow{2}{*}{ Model } & \multirow{2}{*}{$\begin{array}{l}\text { Dependent } \\
\text { Variable }\end{array}$} & \multirow{2}{*}{ Intercept } & \multicolumn{8}{|c|}{ Independent Variables } \\
\hline & & & SLG $21 \mathrm{C}$ & SLG_TRA & PRA_INF & PRA_PEOP & ASS TRAD & ASS EMER & SLC_STRA & SLC VIS \\
\hline 1 & TP TRAD & $3.00^{* * *}$ & $0 . \overline{0}$ & -0.07 & $0 . \overline{0}$ & -0.01 & $0.09^{* * *}$ & -0.05 & $0.04^{* * *}$ & -0.02 \\
\hline 2 & TP_LLL & $2.23^{* * *}$ & 0.04 & -0.02 & -0.01 & $0.02^{* *}$ & 0.01 & $0.03^{*}$ & 0.03 & -0.02 \\
\hline 3 & TP_CONN & $1.65^{* * *}$ & $0.05^{*}$ & -0.03 & 0.04 & -0.02 & 0.02 & -0.01 & $0.05^{* *}$ & -0.01 \\
\hline 4 & SP TRAD & $2.52^{* * *}$ & -0.01 & -0.01 & 0.04 & -0.01 & 0.04 & 0.10 & -0.02 & -0.03 \\
\hline 5 & SP LLL & $1.97^{* * *}$ & 0.02 & -0.02 & 0.03 & -0.01 & 0.02 & 0.03 & $0.04^{*}$ & -0.02 \\
\hline 6 & $\mathrm{SP}^{-} \mathrm{CONN}$ & $1.19^{* * *}$ & $0.06^{*}$ & -0.01 & $0.04^{*}$ & -0.01 & -0.01 & 0.01 & $0.05^{*}$ & $-0.06^{*}$ \\
\hline 7 & ICT TP TRAD & $14.68^{*}$ & 2.87 & -0.56 & $2.22^{*}$ & -0.23 & -0.32 & -0.25 & $2.76^{* * *}$ & -2.07 \\
\hline 8 & $\mathrm{ICT}^{-} \mathrm{TP}^{-} \mathrm{LLL}$ & 10.71 & -0.01 & 1.06 & 2.11 & -0.06 & -0.73 & 0.12 & $3.49^{*}$ & -2.74 \\
\hline 9 & $\mathrm{ICT}_{-}^{-} \mathrm{TP}_{-}^{-} \mathrm{CONN}$ & 7.45 & 0.28 & 0.58 & 2.00 & -0.50 & -0.47 & 0.22 & 2.79 & -2.64 \\
\hline 10 & ICT_SP_TRAD & 9.71 & $3.59^{* *}$ & 1.36 & 1.53 & 1.90 & 1.11 & -1.15 & $4.64^{* * *}$ & -6.36 \\
\hline 11 & ICT_SP_LLL & $10.11^{*}$ & 0.17 & 0.83 & 2.19 & -0.48 & -0.05 & 0.69 & $3.21^{*}$ & $-3.81^{*}$ \\
\hline 12 & $\mathrm{ICT} \mathrm{SP} \mathrm{CONN}$ & 1.33 & 1.97 & 0.63 & $2.06^{*}$ & $-0.98^{*}$ & -0.55 & 0.27 & 3.00 & -3.02 \\
\hline
\end{tabular}




\section{Discussion}

A basic assumption in this article has been that school leadership and pedagogical use of ICT emerge from a dialectical interaction between them. As a secondary analysis of SITES 2006, the present study takes a comparative perspective and attempts to understand the school leadership factors that potentially affect the teachers' pedagogical orientations, and how the teacher-level and school-level factors are associated. Eight school leadership constructs were identified through exploratory factor analysis, which cover four areas, namely learning goals encouraged by school leadership, priority for resource allocation to enhance ICT use, types of assessment encouraged by school leadership, and priority of competencies for school leadership to acquire. These constructs not only reflect empirical evidence of principals' perceptions on pedagogy and ICT use, but serve as a possible conceptual framework to understand school leadership and pedagogical use of ICT. Based on these constructs, the findings of the present study clearly indicate that the "priority for school leadership to acquire strategic competencies" plays a crucial role in predicting teacher pedagogical orientations, which suggests the importance of strategic competencies in school leadership in relation to teachers' pedagogical orientations.

Most teachers in Hong Kong are keen to equip their students to be able to cope with public examinations and get good results. Their pedagogical approaches tend to be driven by an examination culture and the teaching contents are guided by examination syllabi and textbooks (Yuen 2000). The findings of this study reveal that Hong Kong principals are mindful of assessment. They encourage teachers to use traditional assessment as well as emerging assessment method. However, associations between teacher-level and school-level constructs in Hong Kong remain unclear. Further empirical studies are desperately needed to improve the understanding of the relations between these two levels.

It is evident that computer access, connectivity, teacher enablement, curriculum resources and technical support in Hong Kong schools have been greatly improved since 1998 (EMB 2004). Nonetheless, all these enabling factors need to be worked out by teachers and school leadership in collaboration. Both teachers and principals play a key role in determining the success of the ICT integration in schools. Teachers' perspectives on educational change are crucial in translating pedagogical innovations into daily classrooms. However, principals' misunderstanding of teacher perspective is considered a major reason for failure of educational change. Thus, principals should become visionary leaders to foster change in teachers' attitude and performance (McGrail 2005). It echoes to the aforementioned findings about the importance of "visionary competence for school leadership".

The findings of this study point to a gap of perceptions between teachers and principals in Hong Kong. The divergence between principals' and teachers' perceptions suggests that these two groups of players have different assumptions, priorities, and understanding to pedagogy and ICT use. How can we narrow the divergence of principals' and teachers' views? If we conceptualize the ICT integration in schools as a learning process for teachers and principals, then it becomes clear that we should find ways to develop teachers and principals with shared understanding, deep meaning about pedagogy and ICT use in the context of $21^{\text {st }}$ century education. In order to bridge the gap of perceptions between teachers and principals, the following suggestions are thus discussed.

Firstly, we should focus teacher professional development on helping teachers to develop deeper understanding of the nature of the challenge that the information era is bringing to education, the kind of curricular and pedagogical change that are necessary to face this challenge and the kinds of technologies and uses that would be supportive of such change. Teacher ICT professional development should interweave the notions of information literacy (EDB 2008) and pedagogical use of ICT, so that teachers could facilitate and develop their students to become information literate and function in the new world economy. ICT professional development for teachers should provide the necessary knowledge and competence that will help teachers analyse and reflect on environmental changes and develop appropriate strategies to make continuous improvement and development in their pedagogical 
practices. Apart from pedagogical integration of ICT, teachers should be aware of various issues arising from ICT leadership and socio-cultural impacts of ICT.

Secondly, being a principal is a complex activity (Wilson and McPake 2000); thus, a similar kind of professional development is also much needed for school principals. The goal in enhancing school leadership for knowledge age has been promoted in the second ICT policy document (EMB 2004) in Hong Kong. In order to support schools to implement the kind of education innovation and change required, a new concept of "e-leadership" (Gurr 2004) is needed. A multi-level leadership, including system-level, school-level, and teacher-level, is also essential. The government should support schools in the development of curriculum leadership at the school level and collaborate with schools and school organizations to develop effective change strategies. As discussed in the aforementioned section, the ICT in education initiative has been embedded as an integral part of the wider education reform, then the ICT implementation in schools should be conducted through coordinated leadership and that the government should play an important role in providing the link between ICT implementation, curriculum reform, teacher professional development and leadership development at system-level. School leadership should have a genuine understanding of the ecology and dynamics of different education initiatives and reforms, which is pivotal to the success of ICT integration. While established views of e-leadership remain important, simply translating these into the new environments is not sufficient. Gurr (2004) argues that "communication, community building and establishing trust seem to be tasks that are more important for leaders in many of these environments" (p. 122). In particular, an "open communication" on the part of principals and teachers is also necessary for educational change to become meaningful and manageable in schools (McGrail 2005). How do we develop principals and teachers to affect the changes of pedagogy and ICT use in schools? What strategies can we use to foster a multi-level collaboration in the implementation of ICT integration? The emergence of further empirical evidence is of course necessary.

\section{References}

Anderson, R. E., \& Plomp, T. (2008). National contexts. In N. Law, W. Pelgrum, \& T. Plomp (Eds.), Pedagogy and ICT use in schools around the world: findings from the IEA SITES 2006 study (pp. 37-66). Hong Kong: Springer.

Bennett, C. K. (1996). Schools, technology, and educational leadership: a framework for change. NASSP Bulletin, 80(577), 57-66.

Cardinal, R. N., \& Aitken, R. F. (2006). Anova for the behavioural sciences researcher. New Jersey: Lawrence Erlbaum Associates, Inc.

Coffland, D. A., \& Strickland, A. W. (2004). Factors related to teacher use of technology in secondary geometry instruction. Journal of Computers in Mathematics and Science Teaching, 23(4), 347-365.

EC (2000). Learning for Life, Learning through Life: Reform Proposals for the Education System in Hong Kong. Hong Kong: Education Commission, Hong Kong SAR Government.

EDB (2008). Right Technology at the Right Time for the Right Task. Consultation Document. Hong Kong: Education Bureau (EDB), Hong Kong SAR Government.

EMB (1998). Information Technology for lear in a New Era: Five-Year Strategy 1998/99 to 2002/03. Hong Kong: Education and Manpower Bureau, Hong Kong SAR Government.

EMB (2004). Empowering Learning and Teaching with Information Technology. Hong Kong: Education and Manpower Bureau, Hong Kong SAR Government.

Flanagan, L. \& Jacobsen, M. (2003). Technology leadership for the twenty-first century principal. Journal of Educational Administration, 41(2), 124-142.

Griffin, M. A. (2001). Dispositions and work reactions: a multi-level approach. Journal of Applied Psychology, 86, 1142-1151.

Gurr, D. (2004). ICT, leadership in education and e-leadership. Discourse: Studies in the Cultural Politics of Education, 25(1), 113-124. 
Hofmann, D. A., Griffin, M. A., \& Gavin, M. B. (2000). The application of hierarchical linear modeling to organizational research. In K. Klein, \& S. W. Kozlowski (Eds.), Multi-level theory, research, and methods in organizations (p. 467-511). San Francisco: Jossey-Bass.

IEA (2008). SITES 2006 Questionnaire. International Association for the Evaluation of Educational Achievement. http://www.sites2006.net/exponent/index.php?section=37. Accessed: 4 February 2009.

Kearsley, G. \& Lynch, B. (1992). Educational leadership in the age of technology: the new skills. Journal of Research on Computing in Education, 25(1), 5-14.

Law, N., \& Chow, A. (2008). Pedagogical orientations in mathematics and science and the use of ICT. In N. Law, W. Pelgrum, \& T. Plomp (Eds.), Pedagogy and ICT use in schools around the world: findings from the IEA SITES 2006 study (pp. 121-179). Hong Kong: Springer.

Law, N., Pelgrum, W. J., \& Plomp, T. (2008). Pedagogy and ICT Use in Schools around the World: Findings from the IEA SITES 2006 Study. Hong Kong: Springer.

Leskes, A., Grogan, W. R., Canham, R. P., \& O’Brien, J. (2003). Designing institutional change. Liberal Education, 89(1), 32-41.

Levin, T., \& Wadmany, R. (2008). Teachers' views on factors affecting effective integration of information technology in the classroom: developmental scenery. Journal of Technology and Teacher Education, 16(2), 233-263.

McGrail, E. (2005). Teachers, technology, and change: English teachers' perspectives. Journal of Technology and Teacher Education, 13(1), 5-24.

Owston, R. D. (2003). School context, sustainability, and transferability of innovation. In R. B. Kozma (Ed.), Technology, innovation, and educational change: a global perspective (pp. 125-162). Eugene, OR: International Society for Technology in Education.

Pelgrum, W. (2008). School practices and conditions for pedagogy. In N. Law, W. J. Pelgrum, \& T. Plomp (Eds.), Pedagogy and ICT use in schools around the world: findings from the IEA SITES 2006 study (pp. 67-120). Hong Kong: Springer.

Pelgrum, W. J., \& Anderson, R. E. (1999). ICT and the emerging paradigm for life long learning. Amsterdam: International Association for the Evaluation of Educational Achievement.

Raudenbush, S., Bryk, A., Cheong, Y. F., Congdon, R., \& du Toit, M. (2004). HLM 6: hierarchical linear and nonlinear modeling. Lincolnwood: SSI Scientific Software International.

Sumner, M., \& Hostetler, D. (1999). Factors influencing the adoption of technology in teaching. Journal of Computer Information Systems, 40(1), 81-87.

Tse, H. H., Dasborough, M. T., \& Ashkanasy, N. M. (2008). A multi-level analysis of team climate and interpersonal exchange relationships at work. The Leadership Quarterly, 19(2), 195-211.

UNESCO (2002). Information and communication technologies in teacher education: a planning guide. Division of Higher Education, UNESCO.

Wilson, V., \& McPake, J. (2000). Managing change in small Scottish primary schools. Is there a small school management style? Educational Management and Administration, 28(2), 119-132.

Yuen, H. K. (2000). Teaching computer programming: a connectionist view of pedagogical change. Australian Journal of Education, 44(3), 240-253.

Yuen, H. K., Law, N. \& Wong, K. C. (2003). ICT implementation and school leadership: case studies of ICT integration in teaching and learning. Journal of Educational Administration, 41(2), 158-170.

Yuen, H. K., \& Ma, W. K. (2002). Gender differences in teacher computer acceptance. Journal of Technology and Teacher Education, 10(3), 365-382.

Zhao, Y., \& Frank, K. A. (2003). Factors affecting technology use in schools: An ecological perspective. American Educational Research Journal, 40(4), 807-840. 